\title{
A EXPANSÃO DO ENSINO SUPERIOR PÚBLICO NO BRASIL E A QUESTÃO DO FINANCIAMENTO NO PERÍODO 1995-2002: \\ o caso da Universidade de Brasília \\ Duscelino Pereira Borges
}

Curso: Mestrado em Sociologia

Data de defesa da dissertação: 27 de setembro de 2005

Orientador: Prof. Dr. Carlos Benedito Martins

\section{Resumo:}

Este trabalho teve por objetivo geral analisar a inserção da Universidade de Brasília (UnB) no contexto da expansão do ensino superior nacional e local, relacionada à questão do financiamento público, no período 1995-2002.

A opção metodológica deste estudo considerou dois momentos distintos de investigação. O primeiro visava à formação de um quadro geral sobre a educação superior no País, com ênfase no nível de graduação das instituições federais de ensino superior, e o financiamento público no período de 1995-2002. Partiu-se, portanto, do geral para o particular, como forma de compreender o caso mais específico da expansão na Universidade de Brasília. No segundo momento, o foco de análise foi a percepção dos agentes da UnB sobre os caminhos percorridos pela instituição no período 1995-2002, tendo por objetivo examinar como se equacionou a questão da expansão de cursos de graduação e do orçamento na universidade.

Nesse procedimento, buscou-se evidenciar eventuais conflitos e consensos no debate ocorrido nas instâncias deliberativas da instituição. Comparando os dados apresentados em todo o sistema 
de ensino superior com aqueles verificados no subcampo em análise, constatou-se que a Universidade de Brasília, e as IFES de modo geral, conseguiu ampliar seus índices de desempenho no nível de graduação, mesmo diante de um quadro de restrição orçamentária. Nesse processo de expansão com a abertura de cursos na graduação, houve uma confluência de fatores internos, entre eles uma vontade da reitoria e de grupos isolados de professores e de alguns dirigentes, e externos, com a política educacional dirigida às IFES e a pressão da própria sociedade que reivindicava uma resposta da universidade à crescente demanda por uma vaga no ensino superior.

Houve, portanto, um esforço institucional em reverter o quadro de limitação dos recursos orçamentários, materiais e humanos, que passa pela busca de alternativas para sua sobrevivência, seja na captação de recursos próprios, seja na modernização de sua gestão e racionalização de suas atividades.

Palavras-chave: ensino superior; expansão; financiamento público 